\title{
Effect of continuous infusion of oxytocin on length of the oestrous cycle and luteolysis in cattle*
}

\author{
J. Kotwica $\dagger$, D. Schams, H. H. D. Meyer and Th. Mittermeier \\ Institut für Physiologie, Südd. Versuchs- und Forschungsanstalt für Milchwirtschaft, Technische \\ Universität München, 8050 Freising-Weihenstephan, Federal Republic of Germany
}

\begin{abstract}
Summary. In Exp. I oxytocin $(60 \mu \mathrm{g} / 100 \mathrm{~kg} /$ day $)$ was infused into the jugular vein of 3 heifers on Days 14-22, 15-18 and 16-19 of the oestrous cycle respectively. In Exp. II 5 heifers were infused with $12 \mu \mathrm{g}$ oxytocin $/ 100 \mathrm{~kg} /$ day from Day 15 of the oestrous cycle until clear signs of oestrus. Blood samples were taken from the contralateral jugular vein at 2 -h intervals from the start of the infusion. The oestrous cycle before and after treatment served as the controls for each animal. Blood samples were taken less frequently during the control cycles. In Exp. III 3 heifers were infused with $12 \mu \mathrm{g}$ oxytocin/ $100 \mathrm{~kg} /$ day for $50 \mathrm{~h}$ before expected oestrus and slaughtered $30-40 \mathrm{~min}$ after the end of infusion for determination of oxytocin receptor amounts in the endometrium. Three other heifers slaughtered at the same days of the cycle served as controls.

Peripheral concentrations of oxytocin during infusion ranged between 155 and $641 \mathrm{pg} / \mathrm{ml}$ in Exp. I and 18 and $25 \mathrm{pg} / \mathrm{ml}$ in Exp. II. In 4 out of 8 heifers of Exps I and II, one high pulse of 15-keto-13,14-dihydro-prostaglandin F-2 $\alpha$ (PGFM) appeared soon after the start of oxytocin infusion followed by some irregular pulses. The first PGFM pulse was accompanied by a transient $(10-14 \mathrm{~h})$ decrease of blood progesterone concentration. High regular pulses of PGFM in all heifers examined were measured between Days 17 and 19 during spontaneous luteolysis. No change in length of the oestrous cycle or secretion patterns of progesterone, PGFM and LH was observed. The number of oxytocin receptors in endometrium was not affected by oxytocin infusion around the time of oestrus. These results suggest that luteolytic events were not significantly influenced by a constant infusion of oxytocin.
\end{abstract}

Keywords: oxytocin; infusion; luteolysis; oestrous cycle length

\section{Introduction}

The best evidence that oxytocin may be involved in the events of luteolysis comes from the immunization against oxytocin of cyclic ewes (Sheldrick et al., 1980; Schams et al., 1983) and goats (Cooke \& Homeida, 1985) in which luteal regression was delayed. Exogenous oxytocin is able to shorten the oestrous cycle when given between Days 3 and 6 of the oestrous cycle in cattle (Armstrong \& Hansel, 1959; Hansel \& Wagner, 1960). These inhibitory effects of exogenous oxytocin on the corpus luteum were absent in hysterectomized heifers. Surges of secretion of prostaglandin (PG) F- $2 \alpha$ at the time of luteolysis occur simultaneously with those of oxytocin in the ewe (Flint $\&$ Sheldrick, 1983) and cow (Schams et al., 1985). A potential source of oxytocin at luteal regression is the corpus luteum itself. Secretion is stimulated by PGF- $2 \alpha$ analogues in the ewe (Flint \& Sheldrick, 1983) and cow (Schallenberger et al., 1984). Oxytocin is also able to stimulate secretion of PGF-2 $\alpha$

\footnotetext{
*Reprint requests to Professor D. Schams.

†Permanent address: Institute of Animal Physiology, University of Agriculture and Technology, 10-718 OlsztynKortowo, Poland.
} 
around the time of luteolysis (Schams et al., 1985). According to a proposed hypothesis for the ewe (McCracken et al., 1984) it is assumed that pulsatile release of PGF-2 $\alpha$ at the time of luteolysis strictly depends on the temporal pulsatile release of oxytocin and down regulation of oxytocin receptor. Continuous intravenous infusion of oxytocin between Days 13 and 21 blocked the rise in uterine oxytocin receptor concentrations and prolonged length of the oestrous cycle in ewes (Flint $\&$ Sheldrick, 1985). The present work was undertaken to investigate whether exogenous oxytocin given before the start of luteolysis exerts effects in cows similar to those observed in ewes.

\section{Materials and Methods}

Animals and treatment. Heifers of the local Fleckvieh and Braunvieh breeds (550-700 kg body weight) were used. Cyclicity was monitored for at least two consecutive oestrous cycles by observation of symptoms of oestrus, measurement of progesterone at 2-day intervals and of $\mathbf{L H}$ in blood samples collected every $8 \mathrm{~h}$ at the time of oestrus. The day after the LH surge was designated as Day 1 of the oestrous cycle.

Surgical procedure and blood sampling. On the day before the start of oxytocin infusion the animals were tranquilized with $2.5-3 \mathrm{ml}$ chloropromazine $(23.3 \mathrm{mg} / \mathrm{ml}$ Combelene, Bayer, Leverkusen, F.R.G.) given i.m. and medical grade polyvinyl catheters ( $1.0 \mathrm{~mm}$ i.d., $2.0 \mathrm{~mm}$ o.d.; Dural Plastics, Dural, NSW, Australia) were inserted into each external jugular vein. One catheter was used for infusion of oxytocin solution and the other for withdrawal of blood samples $(5 \mathrm{ml})$ for hormone analysis. Blood samples were taken at 2-h intervals from the start of oxytocin infusion until 2 days after clear symptoms of oestrus. All blood samples were transferred immediately into centrifuge tubes containing $30 \mu \mathrm{m}$-EDTA (ethylenediaminetetraacetic acid, disodium salt) and $1 \mathrm{mg}$ aspirin, chilled in ice-water for at least $5 \mathrm{~min}$. Then samples were centrifuged at $4^{\circ} \mathrm{C}(3000 \mathrm{~g})$ and plasma was stored at $-20^{\circ} \mathrm{C}$ until analysis.

Oxytocin infusion. Three experiments were performed. In Exp. I heifers $(\mathrm{N}=3)$ were infused with $60 \mu \mathrm{g}$ oxytocin (synthetic, 200 i.u. $/ \mathrm{ml}$ : kindly provided by Sandoz, Basle, Switzerland) $/ 100 \mathrm{~kg}$ body weight/day diluted in sterile saline $(9 \mathrm{~g} \mathrm{NaCl} / 1)$ on Days 14-22, 15-18 or 16-19 of the oestrous cycle. During infusion the concentration of oxytocin in peripheral blood plasma was monitored every $8 \mathrm{~h}$ and was for each of the 3 animals $641 \pm 99,233 \pm 43$ and $155 \pm 6 \mathrm{pg} / \mathrm{ml}$, respectively compared to $4 \cdot 1-8 \cdot 8 \mathrm{pg} / \mathrm{ml}$ before start of infusion. The concentrations of oxytocin during infusion in peripheral blood were many-fold higher than the highest ones observed during spontaneous episodes of release of oxytocin at luteolysis. Therefore, in Exp. II $(\mathrm{N}=5)$ only $12 \mu \mathrm{g}$ oxytocin/100 kg body weight/day were infused from Day 15 until signs of oestrus. Oestrus was checked visually throughout the experiment and confirmed by measuring electrical resistance of vaginal mucus and later by determination of the LH surge. The flow rate of the oxytocin-saline solution was $50 \mathrm{ml} / \mathrm{h}$. The oestrous cycles before and after treatment provided the controls for each animal. Blood samples were taken less frequently during the control cycles. In Exp. III ( 3 heifers) $12 \mu \mathrm{g}$ oxytocin/ $100 \mathrm{~kg}$ body weight/day were infused into the jugular vein for $50 \mathrm{~h}$ around the time of oestrus. At about $30 \mathrm{~min}$ after the end of the infusion heifers were slaughtered. Endometrium was collected and stored in liquid nitrogen until analysis of oxytocin receptor concentrations.

Oxytocin receptor assay. Concentration of oxytocin receptor was estimated according to a modified method of Nissenson et al. (1978). The frozen tissue was homogenized (Micro-Dismembrator ${ }^{\mathbf{R}}$; Braun, Melsungen, F.R.G.) at $-196^{\circ} \mathrm{C}$ by shaking the samples for $50 \mathrm{sec}$ at maximal speed and then cooling them for $60 \mathrm{sec}$ in liquid nitrogen. This procedure was repeated 5 times. Then the frozen powder was thawed, suspended in $10 \mathrm{~mm}$-Tris- $\mathrm{HCl}$ buffer $(\mathrm{pH} 7 \cdot 6)$ containing 1.5 mm-EDTA, 3mM-DTT (dithiothreitol) plus $10 \%$ glycerine and kept at $0-4^{\circ} \mathrm{C}$ in the next steps. EDTA was added to remove oxytocin from the receptor (Pearlmutter \& Soloff, 1979). DTT inactivates oxytocin by reducing its -S-S-bonds. The suspension of the homogenate was centrifuged at $3000 \mathrm{~g}$ for $20 \mathrm{~min}$ and the supernatant again at $280000 \mathrm{~g}$ for $60 \mathrm{~min}$. The $280000 \mathrm{~g}$ pellet was resuspended in about $2 \mathrm{ml} 10 \mathrm{~mm}$-Tris-HCl buffer to a final protein concentration of $2-4 \mathrm{mg} / \mathrm{ml}$ and used for the receptor assay. Specific binding of oxytocin was measured by incubation of this suspension with 5 different (range 1-10 nM) concentrations of $\left[{ }^{3} \mathrm{H}\right]$ oxytocin (Amersham Buchler, Braunschweig, F.R.G.) in the absence or presence of a 100-2000-fold excess of unlabelled oxytocin. For the assay procedure, $50 \mu 1$ of pellet suspension ( $100 \mu \mathrm{g}$ protein) were combined with $50 \mu \mathrm{l} 45 \mathrm{~mm}$-Tris- $\mathrm{HCl}, 15 \mathrm{~mm}-\mathrm{MnCl}_{2}, \mathrm{pH} 7.6$ containing a variable amount of $\left[{ }^{3} \mathrm{H}\right]$ oxytocin $(3-30 \mathrm{nM})$ and then $50 \mu \mathrm{l}$ of $45 \mathrm{~mm}-\mathrm{Tris}-\mathrm{HCl}(\mathrm{pH} 7.6$ with or without unlabelled oxytocin $(3 \mu \mathrm{M})$ were added. Incubation was performed for $60 \mathrm{~min}$ at $20^{\circ} \mathrm{C}$ and terminated by addition of $3 \mathrm{ml}$ ice-cold Tris- $\mathrm{HCl}$ buffer followed immediately by rapid filtration (under vacuum) through a $0.2 \mu \mathrm{m}$ cellulose acetate filter (Sartorius, Göttingen, F.R.G.). The test tubes and filter were rinsed twice with ice-cold buffer. The filters were placed into scintillation counting tubes, $12 \mathrm{ml}$ scintillation fluid (Rialuma ${ }^{\circledR}$ Baker Chemicals, Phillippsburg, NJ, U.S.A.) were added and radioactivity was measured. Concentration of oxytocin receptor was determined by means of Scatchard analysis (1949). Within the calculation, values were corrected for non-specific binding and expressed in terms of $\mathrm{fmol} / \mathrm{mg}$ protein. Sensitivity of the assay was $130 \mathrm{fmol} / \mathrm{mg}$ protein. Inter- and intraassay coefficients of variation for the assay were 13.2 and $11.5 \%$, respectively.

Hormone analyses. PGFM was measured in a direct RIA using highly specific antibodies kindly donated by Dr W. Schlegel (Universitätsfrauenklinik, Münster, F.R.G.). These antibodies showed a slight cross-reaction with PGEM (1.4\%), PGF-2 $\alpha(0.8 \%)$, PGE-2 and PGAM $(0 \cdot 2 \%)$ and $<0.1 \%$ with 6-keto-PGF- $1 \alpha$, PGA-2 and PGE. 
Samples of plasma $(50 \mu \mathrm{l})$ were assayed in duplicate. PGFM standard was prepared in bovine plasma. The intra- and interassay coefficients of variation (CV) for control samples were 12.3 and $19 \%$, respectively. The limit of sensitivity was $80-200 \mathrm{fmol} / \mathrm{ml}$.

LH was determined according to the method of Schams \& Karg (1969) using a specific antibody against bovine LH. Sensitivity of the procedure was $0.4 \mathrm{ng} / \mathrm{ml}$. Interassay $\mathrm{CV}$ was in the range $11.5-18.6 \%$ and the intra-assay $\mathrm{CV}$ was $5 \cdot 6-8 \cdot 1 \%$, respectively.

The progesterone assay (Hoffman et al., 1973) was modified to a direct test (unextracted plasma) using $25 \mu \mathrm{l}$ blood plasma. Standard was prepared in progesterone-free bovine plasma. Sensitivity of the assay was $1 \mathrm{pmol} / \mathrm{ml}$. Interassay $\mathrm{CV}$ was in the range between 11 and $16 \cdot 9 \%$.

Oxytocin was analysed in the plasma samples taken every $8 \mathrm{~h}$ by RIA according to the method described by Schams (1983). It was extracted and concentrated from $0.5 \mathrm{ml}$ plasma with SEP-PAK $\mathrm{C}_{18}$ cartridges (Waters Assoc., Milford, MA, U.S.A.), using tetrahydrofuran for elution. Sensitivity of the procedure was $0.3 \mathrm{pg} / \mathrm{ml}$. The interassay $\mathrm{CV}$ for control samples was in the range of $7 \cdot 6-19 \%$ and the intra-assay CV was $6 \cdot 2-6 \cdot 5 \%$.

Statistical analysis. Differences between means were tested for significance by Student's $t$ test.

Table 1. Length of the oestrous cycle in heifers before, during and after treatment with oxytocin in Exps I and II

\begin{tabular}{|c|c|c|c|c|}
\hline \multirow[b]{2}{*}{ Exp. } & \multirow{2}{*}{$\begin{array}{c}\text { Heifer } \\
\text { no. }\end{array}$} & \multicolumn{3}{|c|}{ Length of oestrous cycle (days) } \\
\hline & & Before treatment & During treatment & After treatment \\
\hline I & $\begin{array}{l}111 \\
112 \\
113\end{array}$ & $\begin{array}{l}18 \\
20 \\
21\end{array}$ & $\begin{array}{l}19 \\
22 \\
23\end{array}$ & $\begin{array}{l}19 \\
20 \\
20\end{array}$ \\
\hline Mean \pm s.d. & & $19 \cdot 7 \pm 1 \cdot 5$ & $21 \cdot 3 \pm 2 \cdot 0$ & $19 \cdot 7 \pm 0 \cdot 6$ \\
\hline II & $\begin{array}{l}11 \\
12 \\
13 \\
24 \\
25\end{array}$ & $\begin{array}{l}19 \\
20 \\
20 \\
24 \\
20\end{array}$ & $\begin{array}{l}21 \\
20 \\
20 \\
25 \\
20\end{array}$ & $\begin{array}{l}20 \\
20 \\
20 \\
24 \\
20\end{array}$ \\
\hline Mean \pm s.d. & & $20 \cdot 8 \pm 2 \cdot 2$ & $21 \cdot 2 \pm 2 \cdot 2$ & $20 \cdot 8 \pm 1 \cdot 8$ \\
\hline
\end{tabular}

\section{Results}

Concentrations of oxytocin increased in Exp. I from $4 \cdot 1-8.8 \mathrm{pg} / \mathrm{ml}$ (obtained from 3 control samples taken from each animal before start of infusion) to $155-641 \mathrm{pg} / \mathrm{ml}$ and in Exp. II from $3-5 \cdot 3$ to $16-24 \mathrm{pg} / \mathrm{ml}$ during oxytocin infusion. Neither dose of oxytocin had any influence on the length of the oestrous cycle if compared with control cycles (Table 1). Examples for the effect of oxytocin infusion on progesterone, PGFM and LH blood concentrations are given in Fig. 1 (Exp. I) and Fig. 2 (Exp. II). In both experiments luteolysis occurred between Days 17 and 18 of the cycle, as in the control cycles, except in Heifer 111 (Exp. I) which always had a shorter cycle and in which luteolysis was recorded between Days 16 and 17, and Heifer 11 (Exp. II), in which luteolysis was delayed by 1 day when compared with the next cycle. In 4 out of 8 heifers of Exps I and II, the start of oxytocin infusion was followed by a high episode of PGFM followed by some irregular smaller episodes. The first increase of PGFM caused a temporal decrease of progesterone concentrations. After 14-18 h, however, progesterone concentrations in blood recovered (Fig. 2). In the other 4 heifers no or only very small episodes of PGFM were measured with no visible decrease of progesterone concentrations. In 7 heifers spontaneous clear episodes of PGFM occurred at the normal time of luteolysis. The length of the oestrous cycle was not affected by the infusion (Table 1). In Heifer 111 (Exp. I), in which infusion of oxytocin started at the beginning of luteolysis (according to the progesterone values), the first surge of PGFM was followed by others until luteolysis was completed. 

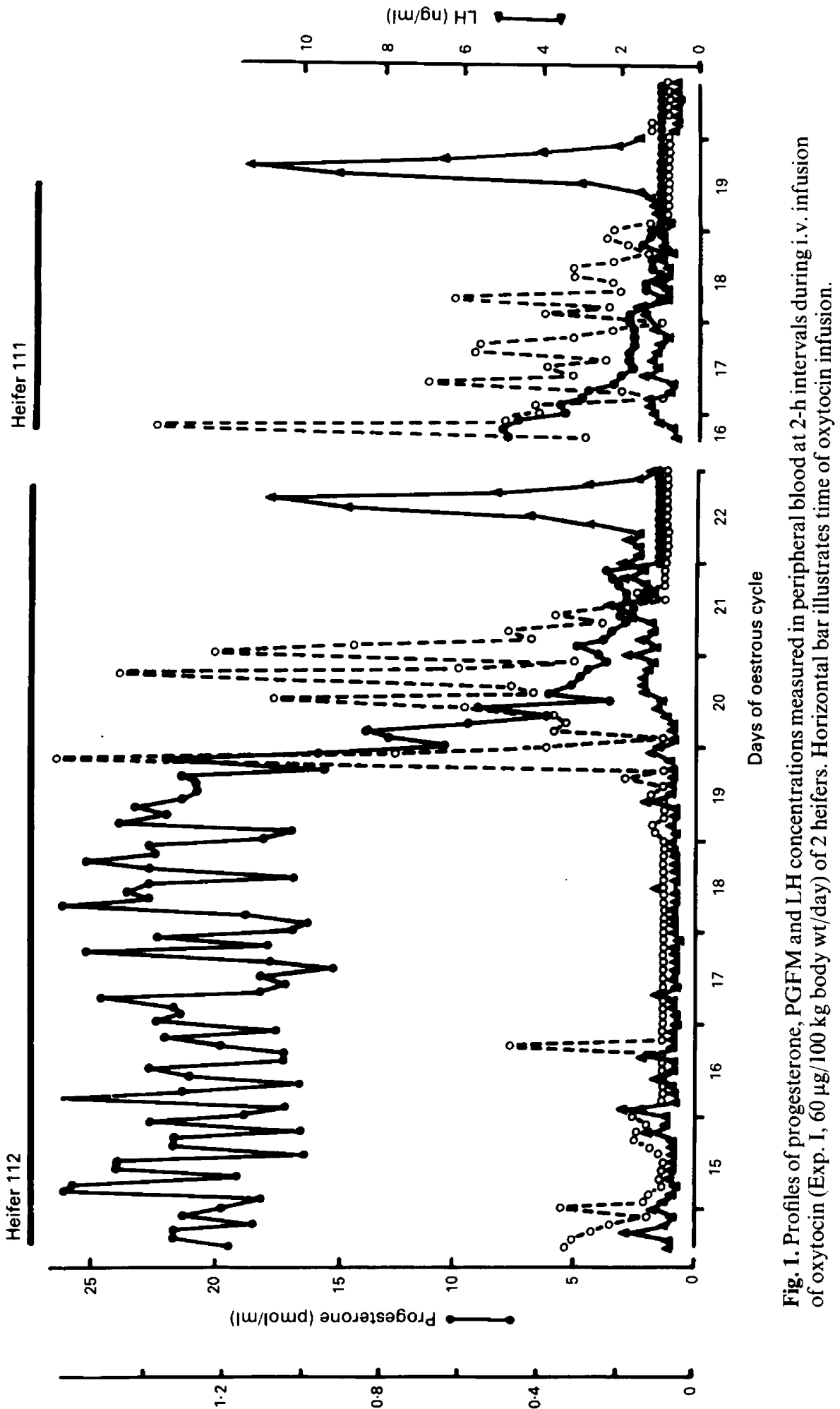

(ןw/ןoud) WJ9d o- - 


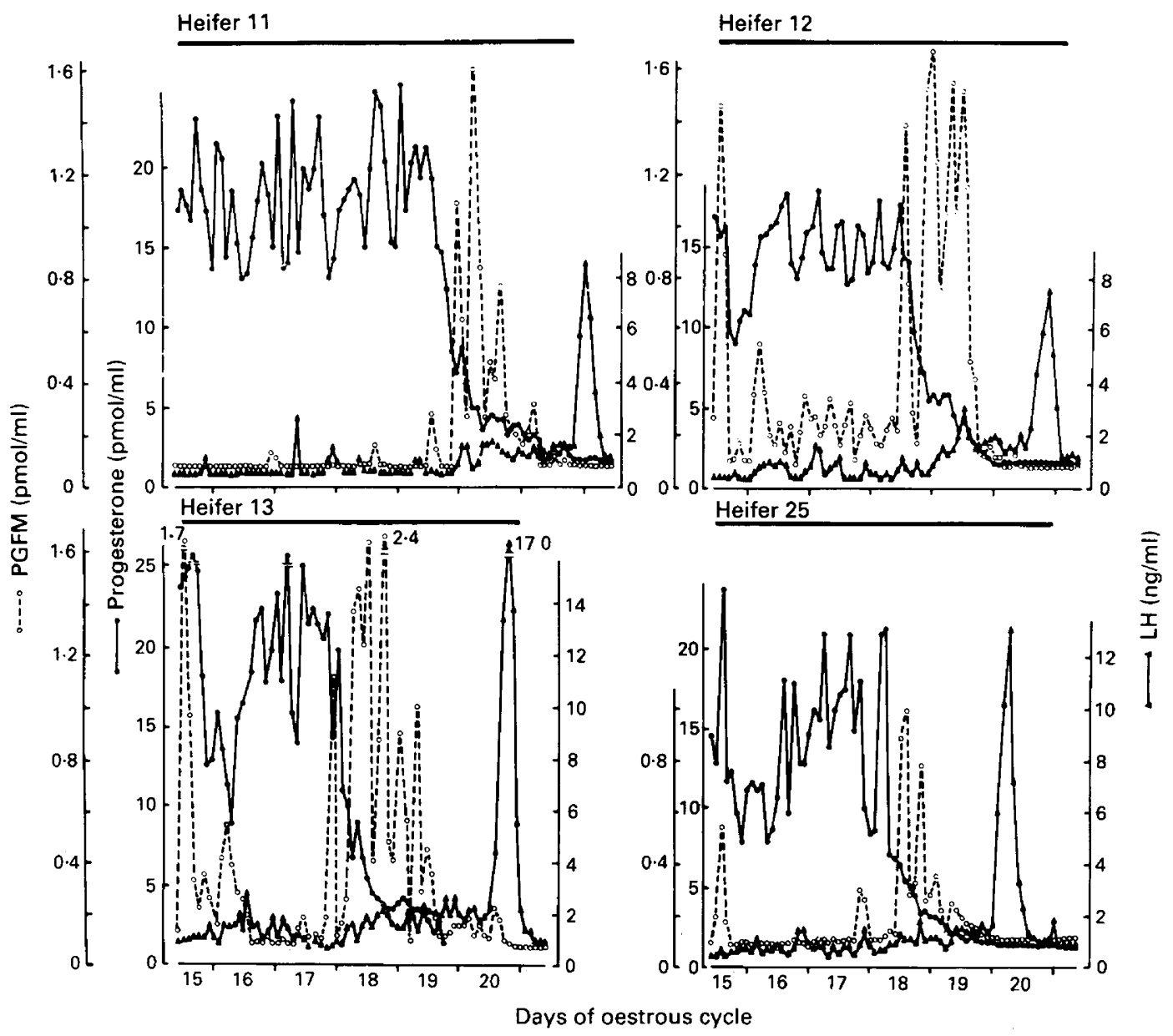

Fig. 2. Concentrations of progesterone, PGFM and LH in peripheral blood samples taken at 2 -h intervals during i.v. infusion of oxytocin $(12 \mu \mathrm{g} / 100 \mathrm{~kg}$ body wt/day) from Day 15 until clear signs of oestrus. Horizontal bar represents time of oxytocin infusion.

The effect of a 50-h infusion of oxytocin around oestrus on receptor concentrations of oxytocin in endometrium (Exp. III) is shown in Table 2. Although statistical analysis for concentration of oxytocin receptor was not performed due to the limited number of animals used in this study, there is clear evidence that infusion of oxytocin did not down regulate concentration of its own receptor.

\section{Discussion}

Continuous infusion of oxytocin in cattle beginning at least 2 or 3 days before the start of normal luteolysis did not influence length of the oestrous cycle when compared with control cycles. Hansel \& Wagner (1960) also show that oxytocin (single injection of a high dose) given on Days 15-22 had no effect on cycle length. Treatment did not affect the pulsatile release of PGF-2 $\alpha$ at the time of spontaneous luteolysis. Milvae \& Hansel (1980) found prolonged increases in uterine venous blood after oxytocin treatment during Days 4-6, but no increases in concurrently collected ovarian arterial concentration. Thus, stage of the cycle appears to influence the results obtained. In one animal PGFM seemed to be suppressed for 1 day, but this delay is within the physiological variation. 
Table 2. Concentration of oxytocin receptor in bovine endometrium of untreated and oxytocininfused heifers ( $12 \mu \mathrm{g} / 100 \mathrm{~kg}$ body weight/day) for $50 \mathrm{~h}$ before slaughter

\begin{tabular}{|c|c|c|c|}
\hline & \multirow{2}{*}{$\begin{array}{l}\text { Day of } \\
\text { oestrous } \\
\text { cycle }\end{array}$} & \multicolumn{2}{|c|}{ Oxytocin receptor } \\
\hline & & $\begin{array}{l}\mathrm{fmol} / \mathrm{mg} \\
\text { protein }\end{array}$ & $K_{\mathrm{D}}(\mathrm{nM})$ \\
\hline Untreated & $\begin{array}{r}21 \\
21 \\
1\end{array}$ & $\begin{array}{r}1576 \\
2320 \\
950\end{array}$ & $\begin{array}{l}1.74 \\
1.54 \\
1.30\end{array}$ \\
\hline Treated & $\begin{array}{r}21 \\
21 \\
2\end{array}$ & $\begin{array}{r}1986 \\
1408 \\
660\end{array}$ & $\begin{array}{l}1.35 \\
1.38 \\
1.27\end{array}$ \\
\hline
\end{tabular}

These results are in contrast to those obtained for sheep in which infusion of oxytocin beginning about 1 day before luteolysis (Day 13) delayed return to oestrus and blocked the rise of uterine oxytocin receptor concentrations (Flint \& Sheldrick, 1985). A temporal down regulation of endometrial oxytocin receptors for the pulsatile secretion of PGF-2 $\alpha$ in ewes was assumed by McCracken et al. (1984). However, Sheldrick \& Flint (1986) have shown that, once formed ovine endometrial oxytocin receptors are not down-regulated by exogenous oxytocin. In this respect, as shown in Exp. III, there appear to be distinct similarities between sheep and cows. From our experiments it is difficult to know whether receptors were present at the beginning of the infusion at Day 15. From another experiment in which heifers were slaughtered at defined days of the oestrous cycle, concentrations of endometrial oxytocin receptor decreased continuously from Day 1 to Days 6-7, remained undetectable during the luteal phase and increased again on Days 17-18 at the time of luteolysis and reached a maximum at oestrus (Schams, 1987). We cannot exclude from that experiment that a few receptors $(<130 \mathrm{fmol} / \mathrm{mg}$ protein) formed before Days 17-18. The response of PGFM at the beginning of Exps I and II in 4 animals would allow such an assumption. The nonresponding heifers at least would indicate that oxytocin receptors were not formed on Day 15. Episodic release of ovarian oxytocin at 12-h intervals stimulated by a 20-min infusion of PGE-2 on Days 13 and 14 of the oestrous cycle $(\mathrm{N}=5$ heifers) did not increase sensitivity of the endometrium. Peripheral oxytocin concentrations increased up to $70 \mathrm{pg} / \mathrm{ml}$ blood plasma but no response of PGF-2 $\alpha$ was measured (D. Schams \& J. Kotwica, unpublished data). We assume that down regulation of endometrial oxytocin receptors is not involved during the events of luteolysis in cattle. Another possibility is uterine refractoriness followed after administration of oxytocin as shown in progestagen + oestradiol-primed ovariectomized ewes (Sheldrick \& Flint, 1986) in which refractoriness appeared to be due to mechanisms other than the down regulation of the oxytocin receptor.

If such a refractoriness exists in cattle it seems not to be influenced by a constant infusion of oxytocin. The results could indirectly support the hypothesis that endometrial oxytocin receptor during the oestrous cycle is mainly regulated by the ratio of progesterone and oestrogens (Nissenson et al., 1978; Soloff et al., 1983; Fuchs et al., 1983) and the results indicate that, for the release of PGF-2 $\alpha$, ovarian oxytocin is not absolutely necessary in cattle as it seems to be in ewes. Even in sheep the situation is not yet clear. Pulsatile surges of oxytocin at the time of luteolysis appeared a few minutes after PGF- $\alpha \alpha$ pulses (Moore et al., 1986). A pulsatile release of PGFM was observed in ovariectomized ewes treated with oestrogen (Lye et al., 1983). Therefore, if the signal for uterine PGF- $2 \alpha$ release comes from the ovary, factors other than oxytocin, perhaps oestrogens, seem to fulfil this function. Extension of luteal function after destruction of ovarian follicles on Days 9, 12 or 15 after oestrus in cattle (Villa-Godoy et al., 1985) would support such a supposition. 
However, this assumption implies that the endometrium at that time is oestrogen sensitive. Oestrogen receptor accumulation may be blocked by progesterone as shown in rats (Okulicz, et al., 1981) and so the action of progesterone on the uterus should be at first diminished, probably by inducing loss of its own receptor (McCracken et al., 1984). On the other hand data reviewed by Kindahl et al. (1979) indicate that progesterone secretion at the end of the oestrous cycle in cattle may be necessary for pulsatile release of PGF-2 $\alpha$. This is also supported by the fact that PGF-2 $\alpha$ release continues until progesterone is reduced to basal levels (Figs $1 \& 2$ ). Similar results were obtained with untreated animals (Schallenberger et al., 1986). It is also possible that a signal for release of PGF-2 $\alpha$ and initiation of luteolysis originates from the uterus itself. Shortening of the oestrous cycle in sheep (Woody et al., 1967) and cattle (Ginther, 1970) by progesterone injections in the first days of oestrous cycle may support this assumption, indicating that the time of progesterone dominance during the oestrous cycle may be restricted. In the present study, in 4 out of 8 heifers a distinct but single PGFM peak was observed $2 \mathrm{~h}$ after the start of oxytocin infusion. Possibly this increase of PGFM can only be observed by giving oxytocin in pulses of short duration, because it was also observed after a single intramuscular injection of high concentrations of oxytocin (Betteridge et al., 1984; Lafrance \& Goff, 1985) or intravenous application of a moderate dose (Schams et al., 1985). However, it cannot be excluded that PGF-2 $\alpha$ might be released from the ovary (Milvae \& Hansel, 1983) as in in-vitro experiments.

From our results with cows we can conclude that a constant infusion of oxytocin beginning about 2 days before start of spontaneous luteolysis does not influence the length of the oestrous cycle and episodic secretion of PGFM at luteolysis. The participation of ovarian oxytocin in the events of luteolysis remain to be resolved. A permissive action of oxytocin on luteolysis seems to be more likely than a direct one.

We thank Mrs C. Braun for skilful technical assistance; the Deutsche Forschungsgemeinschaft for financial support; and Alexander von Humboldt Foundation for the postdoctoral fellowship (J. K.).

\section{References}

Armstrong, D.T. \& Hansel, W. (1959) Alteration of the bovine estrous cycle with oxytocin. J. Dairy Sci. 42, $533-542$.

Betteridge, K.J., Randall, G.C.B., Eaglesome, M.D. \& Sugden, E.A. (1984) The influence of pregnancy on PGF $_{2 \alpha}$ secretion in cattle. I. Concentrations of 15 . keto-13,14-dihydroprostaglandin $F_{2 \alpha}$ and progesterone in peripheral blood of recipients of transferred embryos. Anim. Reprod. Sci. 7, 195-216.

Cooke, R.G. \& Homeida, A.M. (1985) Suppression of prostaglandin $F_{2 \alpha}$ release and delay of luteolysis after active immunization against oxytocin in the goat. $J$. Reprod. Fert. 75, 63-68.

Flint, A.P.F. \& Sheldrick, E.L. (1983) Evidence for a systemic role of ovarian oxytocin in luteal regression in sheep. J. Reprod. Fert. 67, 215-225.

Flint, A.P.F. \& Sheldrick, E.L. (1985) Continuous infusion of oxytocin prevents induction of uterine oxytocin receptor and blocks luteal regression in cyclic ewes. J. Reprod. Fert. 75, 623-631.

Fuchs, A.R., Periyasamy, S. \& Soloff, M.S. (1983) Systemic and local regulation of oxytocin receptors in the rat uterus and their functional significance. $C a n$. J. Biochem. Cell Biol. 61, 615-624.

Ginther, O.J. (1970) Effects of progesterone on length of oestrous cycle in cattle. Am. J. vet. Res. 31, 493-496.
Hansel, W. \& Wagner, W.C. (1960) Luteal inhibition in the bovine as a result of oxytocin injections, uterine dilatation and intra-uterine infusions of seminal and preputial fluids. J. Dairy Sci. 43, 796-805.

Hoffmann, B., Kyrein, H.J. \& Ender, M.L. (1973) An efficient procedure for determination of progesterone by radio-immunoassay applied to bovine peripheral plasma. Hormone Res. 4, 302-310.

Kindahl, H., Lindell, J.O. \& Edqvist, L.E. (1979) On the control of prostaglandin release during the bovine estrous cycle. Effects of progesterone implants. Prostaglandins 18, 813-819.

Lafrance, M. \& Goff, A.K. (1985) Effect of pregnancy on oxytocin-induced release of prostaglandin $F_{2 \alpha}$ in heifers. Biol. Reprod. 33, 1113-1119.

Lye, S.J., Sprague, C.L. \& Challis, J.R.G. (1983) Modulation of ovine myometrial activity by estradiol$17 \beta$. The possible involvement of prostaglandins. $\mathrm{Can}$. J. Physiol. Pharmacol. 61, 729-735.

McCracken, J.A., Schramm, W. \& Okulicz, W.C. (1984) Hormone receptor control of pulsatile secretion of $\mathrm{PGF}_{2 a}$ from the ovine uterus during luteolysis and its abrogation in early pregnancy. Anim. Reprod. Sci. 7, $31-55$.

Milvae, R.A. \& Hansel, W. (1980) Concurrent uterine venous and ovarian arterial prostaglandin $F$ concen- 
trations in heifers treated with oxytocin. J. Reprod. Fert. 60, 7-15.

Milvae, R.A. \& Hansel, W. (1983) Prostacyclin, prostaglandin $F_{2 \alpha}$ and progesterone production by bovine luteal cells during the estrous cycle. Biol. Reprod. 29, 1063-1068.

Moore, L.G., Choy,V.J., Elliot, R.L. \& Watkins, W.B. (1986) Evidence for the pulsatile release of PGF $-2 \alpha$ inducing the release of ovarian oxytocin during luteolysis in the ewe. J. Reprod. Fert. 76, 159-166.

Nissenson, R., Flouret, G. \& Hechter, O. (1978) Opposing effects of estradiol and progesterone on oxytocin receptors in rabbit uterus. Proc. natn. Acad. Sci. U.S.A., 75, 2044-2048.

Okulicz, W.C., Evans, R.W. \& Leavitt, W.W. (1981) Progesterone regulation of estrogen receptor in the rat uterus: a primary inhibitory influence on the nuclear fraction. Steroids 37, 463-470.

Pearlmutter, A.F. \& Soloff, M.S. (1979) Characterization of the metal ion requirement for oxytocin-receptor interaction in rat mammary gland membranes. $J$. biol. Chem. 254, 3899-3906.

Scatchard, G. (1949) The attractions of proteins for small molecules and ions. Ann. N.Y. Acad. Sci. 51, 660-672.

Schallenberger, E., Schams, D., Bullermann, B. \& Walters, D.L. (1984) Pulsatile secretion of gonadotrophins, ovarian steroids and oxytocin during prostaglandininduced regression of the corpus luteum in the cow. $J$. Reprod. Fert. 71, 493-501.

Schallenberger, E., Meyer, H.H.D., Schams, D. \& Karg, H. (1986) Alternative hormonale Mechanismen zur Erhaltung der Frühgravidität beim Rind. In Fortschritte der Fertilitätsforschung FDF 13, pp. 16-23. Ed. C. Schirren. Grosse Verlag, Berlin.

Schams, D. (1983) Oxytocin determination by radioimmunoassay. III. Improvement to subpicogram sensitivity and application to blood levels in cyclic cattle. Acta endocr., Copenh. 103, 180-183.
Schams, D. (1987) Luteal peptides and intercellular communication. J. Reprod. Fert. 34, 87-99.

Schams, D. \& Karg, H. (1969) Radioimmunologische LH-Bestimmung in Blutserum vom Rind unter besonderer Berücksichtigung des Brunstzyklus. Acta endocr., Copenh. 61, 96-103.

Schams, D., Prokopp, S. \& Barth, D. (1983) The effect of active and passive immunization against oxytocin on ovarian cyclicity in ewes. Acta endocr., Copenh. 103, 337-344.

Schams, D., Schallenberger, E., Meyer, H.H.D., Bullermann, B., Breitinger, H.J., Enzenhöfer, G., Koll, R., Kruip, T.A.M., Walters, D.L. \& Karg, H. (1985) Ovarian oxytocin during the estrous cycle in cattle. In Oxytocin: Clinical and Laboratory Studies, pp. 317-334. Eds J. A. Amico \& A. G. Robinson. Excerpta Medica, Amsterdam.

Sheldrick, E.L. \& Flint, A.P.F. (1986) Transient uterine refractoriness after oxytocin administration in ewes. J. Reprod. Fert. 77, 523-529.

Sheldrick, E.L., Mitchell, M.D. \& Flint, A.P.F. (1980) Delayed luteal regression in ewes immunized against oxytocin. J. Reprod. Fert. 59, 37-42.

Soloff, M.S., Fernstrom, M.A., Periyasamy, S., Soloff, S., Baldwin, S. \& Wieder, M. (1983) Regulation of oxytocin receptor concentration in rat uterine explants by estrogens and progesterone. Can. J. Biochem. Cell Biol. 61, 615-630.

Villa-Godoy, A., Ireland, J.J., Wortman, J.A., Ames, N.K., Hughes, T.L. \& Fogwell, R.L. (1985) Effect of ovarian follicles on luteal regression in heifers. $J$. Anim. Sci. 60, 519-527.

Woody, C.O., First, N.L. \& Pope, A.L. (1967) Effects of exogenous progesterone on estrous cycle length. $J$. Anim. Sci. 26, 139-141.

Received 25 August 1987 